\title{
PEMBERIAN UPAH PEMOTONGAN HEWAN QURBAN MENURUT HUKUM ISLAM (STUDI PADA MASYARAKAT TANJUNG BARULAK KAB. TANAH DATAR)
}

\author{
Hendri
}

Fakultas Syariah LAIN Bukittinggi, hendridatuak7@gmail.com

\author{
Andriyaldi
}

Fakultas Syariah LAIN Bukittinggi, akbiandriyaldi@gmail.com

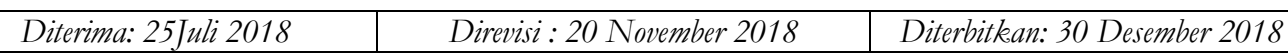

\begin{abstract}
Every year Muslims commemorate the feast of Idhul Adha. One form of celebration is done by sacrificing. Sacrifice is an amaliyah service whose provisions are regulated in Islam. Sacrifice according to etymology comes from Arabic, namely qaraba which means close. The word qurban is commensurate with the word aludhiyyat which is defined as the name of an animal slaughtered on the Idbul Adha feast day and tasyrike days to draw closer to Allah. Whereas the term sacrifice means the slanghter of certain animals with the intention of drawing closer to Allah SWT, which is performed on the feast of Idbul Adha or in the days of Tasyrike which is the 11th, 12th and 13th of Dhulbijah. However, in Indonesia the implementation of slaughtering sacrificial animals in each region is carried out differently. Especially giving wages for slanghtering sacrificial animals. This article uses the analytical content method for the syllables' arguments and also uses the field research method, which is to gather information in the field related to the wages of slanghtering sacrificial animal sacrifices that occur in the middle of the community, especially the Tanjung Barulak district. Tanah Datar. The implementation of slanghtering sacrificial animals in the middle of the community is carried out differently. This is because this is a tradition that has been passed down for generations, both wages given in the form of meat, head, feet or parts of sacrificial animals are a reward for people who cut or clean sacrificial animals. The wages were still given but did not take from the sacrificial animal and then replaced the wages in the form of money taken or requested and collected from the sacrificial participants.
\end{abstract}

Keywords: Upab, Pemotongan Hewan Qurban, Tanjung Barulak

\begin{abstract}
Abstrak
Tiap tabun Umat Islam memperingati hari raya Idhul Adha. Salah satu bentuk perayaannya dilakukan dengan berkurban. Ibadah kurban merupakan ibadah amaliyah yang ketentuannya sudah diatur dalam Islam. Kurban menurut etimologi berasal dari Bahasa Arab, yaitu qaraba yang artinya dekat. Kata qurban sepadan dengan kata al-udhiyyat di defenisikan sebagai nama hewan yang disembelih pada hari raya Idbul Adha dan hari-hari tasyrik untuk mendekatkan diri kepada Allah. Sedangkan kurban secara istilah diartikan penyembeliban bewan tertentu dengan niat mendekatkan diri kepada Allab SWT, yang dilakukan pada hari raya Idbul Adha atau pada hari-hari tasyrik yaitu tanggal 11, 12 dan 13 Drulhijah. Namun di Indonesia pelaksanaan penyembelihan hewan kurban pada tiap tiap daerah dilaksanakan berbeda-beda. Khususya pemberian upab pemotongan bewan kurban. Artikel ini menggunakan metode konten analitis terbadap dalil-dalil syara' dan juga menggunakan metode field research yaitu menggali informasi di lapangan terkait dengan upab penyembeliban hewan kurban hewan kurban yang terjadi di tengah tengah masyarakat khususnya daerah Tanjung Barulak Kab. Tanah Datar. Pelasaksanaan peyembeliban hewan kurban ditengah tengah masyarakat dilaksanakan berbeda-beda. Hal ini disebabkan karena bal ini merupakan tradisi yang sudah turun temurun, kedua upab yang diberikan dalam bentuk daging, kepala, kaki atau bagian dari hewan kurban merupakan sebagai balas jasa terhadap orang yang memotong atau membersibkan bewan kurban. Jika memang upab tersebut tetap diberikan maka tidak mengambil dari bagian hewan kurban namun mengganti upah tersebut berupa uang yang diambil atau diminta yang dipungut dari para peserta kurban.
\end{abstract}

Kata Kunci: Upah, Pemotongan Hewan Qurban, Tanjung Barulak. 


\section{PENDAHULUAN}

Dalam Islam terdapat dua kategori ibadah. Pertama ibadah khashash adalah ibadah yang ketentuan dan cara pelaksanaannya secara khusus ditetapkan oleh nash, seperti: shalat, zakat, puasa, haji, kurban, akikah dan lain sebagainya. Kedua, Ibadah 'Ammah adalah yaitu semua perbuatan yang baik dilakukan dengan niat yang baik dan semata-mata ikhlas karena Allah SWT, seperti: makan, minum, bekerja, amar ma'ruf nabi munkar, berlaku adil, berbuat baik kepada orang lain dan sebagainya. Salah satu ibadah yang tiap tahun datang adalah ibadah kurban yang termasuk kedalam ibadah khashash. Kurban merupakan salah satu bentuk cara kita mengagungkan allah SWT dan mengharapkan pahalanya, kurban merupakan hewan yang disebmbelih pada Hari Raya Idhul adha dan hari tasyrik dalam rangka mendekatkan diri kepada allah SWT. Sesuai dengan firman allah SWT dalam surat AlKautsar ayat 1-3 da dalam hadis nabi yang diwirayatkan oleh ahmad dan ibnu majah. Dari dua sumber tersebut sebagian ulama menetapkan bahwa hukum melakukan kurban adalah wajib bagi yang mampu. Pelaksanaan ibadah kurban tiap tahunnya di tengah tengah masyarakat pun berbeda-beda satu sama lainnya. Ada juga yang menjalankan sesuai dengan apa yang dituntut syari'ah, namun ada juga yang melaksanakan dengan nilai-nilai luhur tetapi tidak dijelaskan secara gambang dalam Islam. Salah satunya adalah tentang penyembelihan hewan kurban baik dari tata caranya maupun dari waktunya. Salah satu hal yang masih dilakukan di tengah masyarakat yaitu terkait dengan upah penyembelihan hewan kurban serta upah pembersihan hewan kurban. Masih ditemukan di Ketika penyembelhan hewan kurban dilaksanakan maka bagi orang yang menyembelih dan membersihkan hewan kurban mendapat bagian dari hewan kurban.

\section{METODE PENULISAN}

Dalam Penelitian ini penulis menggunakan dua metode inti yaitu, konten analisis terhadap dalil-dalil syara' dan juga metode field research yaitu menggali informasi di lapangan terkait dengan upah penyembelihan hewan kurban hewan kurban yang terjadi di tengah tengah masyarakat khususnya daerah Tanjung Barulak Kab. Tanah Datar.

\section{PENGERTIAN, DASAR HUKUM, RUKUN SERTA TATA CARA PENYEMBELIHAN HEWAN KURBAN}

Kurban menurut etimologi berasal dari Bahasa Arab, yaitu qaraba yang artinya dekat. Kata qurban sepadan dengan kata al-udbiyyat di defenisikan sebagai nama hewan yang disembelih pada hari raya Idhul Adha dan harihari tasyrik untuk mendekatkan diri kepada Allah. ${ }^{1}$ Sedangkan kurban secara istilah diartikan penyembelihan hewan tertentu dengan niat mendekatkan diri kepada Allah SWT, yang dilakukan pada hari raya Idhul Adha atau pada hari-hari tasyrik yaitu tanggal 11, 12 dan 13 Dzulhijah. ${ }^{2}$ Kurban juga berasal dari kata $A l$ Udhbiyah dan $A d h$ Dhabiyyah, yaitu nama binatang sembelihan seperti: unta, sapi dan kambing yang disembelih pada hari raya kurban dan hari-hari tasyrik sebagai taqarrub kepada Allah SWT. ${ }^{3}$

Abdurahman Al-Jaziri berpendapat bahwa kurban dalam bahasa Arab dikenal dengan sebutan Udhbiyah atau Idhbiyah. Keduanya adalah istilah untuk hewan ternak yang disembeli pada hari nahar untuk mendekatkan diri pada allah SWT, baik orang yang dikenai taklif (kurban) itu sedang

\footnotetext{
${ }^{1}$ Jaih Mubarok, Fiqih Kontemporer Dalam Bidang Peternakan, (Bandung: Pustaka Setia, 2003), h. 144

2 Abdul Aziz Dahlan, Ensiklopedi Hukum Islam, (Jakarta: PT Ichtiar Baru van hoeve, 2003), Cet. 1, Jilid. 6, h. 994

3 Sayyid Sabiq, Fiqh Sunnah, terjemahan Khairul Amru Harahap dan Masrukhin, judul asli "Fiqh As-Sunnah”, (Jakarta: Cakrawala Publising, 2008), jilid 3, Cet. 1. h. 155
} 
melaksanakan haji ataupun tidak, berdasarkan kesepakatan tiga imam mazhab. Malikiyah menyangkal pendapat tersebut. Mereka berpendapat bahwa kurban ini tidak dituntut bagi orang yang sedang melaksanakan haji. ${ }^{4}$

Adapun hukum kurban adalah sunnat, yaitu sunnat 'ain muakead di mana yang melakukannya mendapat pahala dan meninggalkannya tidak mendapat dosa. Ketentuan ini sebenarnya disepakati, akan tetapi Hanafiyah berpendapat, (benar) bahwa kurban itu sunnat ain muakkad, tetapi bagi yang meninggalkannya tidak bisa memperoleh syafaat Nabi Muhammad SAW kelak. ${ }^{5}$ Hanafi mengistilahkan hal itu dengan wajib. Kaum muslimin sepakat bahwa kurban disyariatkan, tetapi tidak wajib, menurut $A$ hlu 'ilmi. ${ }^{6}$ Ibadah kurban adalah sunnah maukkadah. Bagi yang mampu melakukannya, lalu meninggalkan ibadah itu, maka ia dihukum makhruh.

Menurut ilmu fiqih, bahwa kurban itu hukumnya adalah sunnah muakkadah, yang derajat pahalanya lebih tinggi dari sunnah biasa. Ada para ulama yang menyatakan hukumnya wajib, berdasarkan pada firman Allah SWT dalam Al-Quran Surat Al-Kautsar ayat (2):

Ketentuan yang disyari'atkannya kurban telah ditegaskan dalam Alquran, Allah SWT berfirman: Maka dirikanlah shalat karena Tubanmu dan berkurbanlah. (QS. Al-Kausar: 2)

Dalam riwayat Muslim dari Ummi Salamah. Nabi SAW yang diriwayatkan oleh muslim menegaskan:

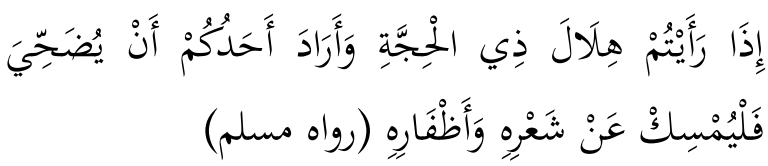

${ }^{4}$ Abdurrahman Al- Jaziri, Figh Empat Mazhab, terjemahan Chatibul Umam dan Abu Hurairah, judul asli "Al-Figh 'Ala Al-Madzabih Al-Arba'ah, Jakarta: Darul Ulum Pres, 2002), Jilid. 4, h. 351

${ }^{5}$ Ibid, h. 352

6 Sa'di Abu Habieb, Ensiklopedi Ijmak, terjemahan M. Sahal Machfudz dan A. Mustofa Bisri, (Jakarta: PT. Pustaka Firdaus, 2006), Cet. IV, h. 390
Apabila kamu melihat bulan Drulbijjah dan menghendaki untuk berkurban, maka pelibaralah rambut dan kuku binatang yang akan dikurbankan" (HR. Muslim). ${ }^{7}$

Sabda beliau ingin berkurban adalah dalil bahwa ibadah ini sunnah bukan wajib. Diriwayatkan dari Abu Bakar dan Umar, bahwa mereka berdua belum pernah melakukan kurban untuk keluarga mereka berdua, lantaran takut kalau-kalau dianggap sebagai hal yang wajib. ${ }^{8}$

Syafi'iyah berpendapat bahwa berkurban itu hukumnya sunnat 'ain bagi perorangan dan sunnat kifayah satu keluarga dalam satu rumah atau banyak rumah yang nafkah mereka itu dalam tanggungan satu orang. Ini berarti bahwa apabila orang yang wajib memberikan nafkah tadi telah mengeluarkan kurban untuk mereka, maka tuntutan berkurban bagi mereka itu gugur dan ini tidak pantas menafikan sunnatnya berkurban bagi masing-masing mereka tadi. Berkurban merupakan amal yang paling dicintai Allah SWT pada saat hari raya Idul Adha. Sebagaimana sabda Nabi SAW yang diriwayatkan oleh At-Tirmidzi dari Aisyah ra.

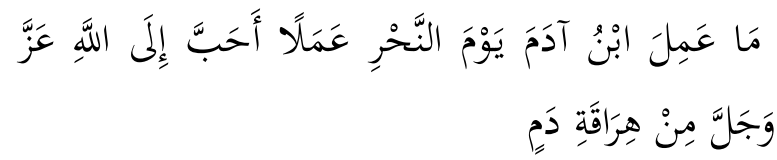

Tidak ada suatu amal anak. Adam pada hari raya kurban yang lebih dicintai Allah selain menyembelib kurban (HR. At Tirmidzi). ${ }^{10}$

Di kalangan para ulama masih terdapat perbedaan pendapat mengenai kewajiban berkurban ini. Jumhur ulama berpendapat,

7 Abû al-Husayn Muslim ibn al-Hajjaj alQusyayri al-Naysaburi, Shabih Muslim, kitab al-Adhabi Bâb Nahâ Man Dakhala 'Alaybi 'Asyr Dzilhijjâh wa Huwa Murîdu, (Beirut: Dar al-Kutub al-Ilmiyah, 1991 M/1412 H), jilid I, hadîts 3655, h. 950.

${ }^{8}$ Sayyid sabiq, op. cit., terjemahan Kamaludin A. Marzuki, judul asli "Fiqhus sunnab", (Bandung: PT. Alma'arif, 1998), jilid 13, cet. 10, h. 157

${ }_{9}$ Abdurrahman Al-Jaziri, op. cit., h. 35

10 Abu Isa Muhammad ibn Isa ibn Saurat AlTirmidzi, Sunan Tirmidzi, Kitab al-Adhabi, Bab Ma ja a fi Fadbil-Udbihiyyah, (Mesir: Mushthapa al-Babi al-Halabi wa Awladuhu, ([tth]), jilid IV, h. 83 (selanjutnya disebut at-Tirmidzi) 
bahwa berkurban merupakan suatu amalan yang disunnahkan. Di antara yang berpendapat demikian itu adalah Imam Malik. Ia mengatakan: "Aku tidak menyukai seseorang yang mampu tetapi tidak melakukannya". ${ }^{11}$ Pendapat yang sama juga dikemukakan Imam Asy-Syafi'i. ${ }^{12}$ Sedangkan Rabi'ah, Al-Auza'i, Abu hanifah, Al-Laits dan sebagian dari ulama Malikiyah berpendapat, bahwa berkurban merupakan amalan yang diwajibkan bagi orang hidup dalam kemudahan (mampu). ${ }^{13}$

Di samping itu, Ibnu Majah meriwayatkan dari Abu Hurairah yang dalam telaahan Muhammad Nashir al-Din al-Albani bernilai hasan. Rasululullah menyatakan:

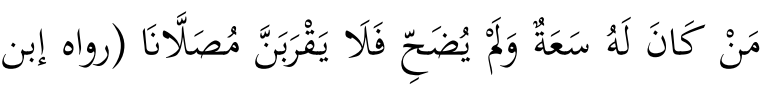

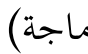

Siapa saja yang memiliki kelapangan (rezeki), namun ia tidak berkurban, maka janganlab ia mendekati tempat shalat (Idhul Adha) kami (HR. Ibn Majah). ${ }^{14}$

Beranjak dari hadis tersebut dalam pandangan Imam Malik, berkurban itu hukumnya wajib. Hal yang senada diungkapkan oleh Imam Abu Hanifah, hanya saja menurutnya berlaku bagi orang yang menetap di suatu negara dan dalam keadaan mampu, yaitu memiliki harta satu nisab. Akan tetapi, pandangan bahwa berkurban itu wajib ditolak oleh hadis lain. Dinyatakan demikian karena dalam riwayat Al-Daruquthni dari 'Abd Allah Ibn Abbas, Rasulullah secara gamblang memberikan klasifikasi sebagai berikut:

11 Muhammad Ibrahim Jannati, Fiqh Perbandingan Lima Mą̧ab, terjemahan Ibnu Alwi Bafaqih, dkk, judul asli, "Durus fi al-Fiqh al-Muqaran", (Jakarta: Cahaya, 2007), Cet. 1, h. 335

${ }^{12}$ Ibid, h. 336

13 Muhammad 'Uwaidah, Kamil, Fiqih Wanita, terjemahan M. Abdul Ghaffar e.m, judul asli " Al-Jami' Fii Fighi An-Nisa",(Jakarta: Pustaka Al-Kautsar, 2008), Cet, II, h. 505

14 Abu 'Abd Allâh Muhammad ibn Yazîd alQazwinî Ibn Mâjah, Sunan Ibn Mâjah, Kitab al-Adhahi Bab al-Adhahi Wâjibat Hiya Am La, ([t.t]): Dar ihya alKutub al-Arabiyah, [tth]), jilid IV h. 2017. (selanjutnya disebut Ibnu Majah)

$$
\text { أُمْرْتُ بِالنَّحْرِ وَلَيْنَ بِوَاجِبٍ (رواه الدارقطني) }
$$

Aku diperintabkan (Allab) untuk berkurban, namun ia bukanlah suatu kewajiban (HR. AlDaruquthni dari 'Abd Allah ibn 'Abbas). ${ }^{15}$

Lebih jelas lagi dalam riwayat Ahmad yang juga berasal dari 'Abd Allah Ibn Abbas, Nabi SAW bersabda:

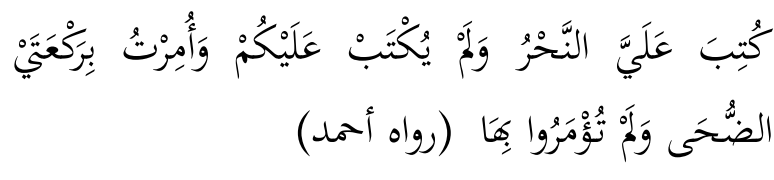

Diwajibkan bagiku berkurban, tetapi tidak diwajibkan bagimu, diperintabkan kepadaku melaksanakan dua rakaat shalat Dhuba, tetapi ia tidak diperintabkan kepadamu (HR. Ahmad). ${ }^{16}$

Dari beberapa riwayat tersebut jelas bahwa Rasulullah SAW menggantungkan kurban pada kemauan umatnya, sehingga tidaklah salah jika Jumhur Ulama menyatakan bahwa hukum berkurban hanyalah sunnat muakkad (sunnah yang dipentingkan) dan makruh bagi orang yang mampu melaksanakannya. ${ }^{17}$ Lebih jauh, Ahmad Isya 'Asyur menjelaskan bahwa hukum berkurban adalah sunnat secara berkelompok. Artinya apabila salah satu anggota keluarga telah berkurban, gugurlah kesunnatan berkurban bagi yang lainnya. Akan tetapi, bila seluruh keluarga tidak ada yang berkurban (padahal mampu untuk berkurban), maka hukumnya menjadi makrub bagi keluarga tersebut. ${ }^{18}$

15 Ubayd Allâh ibn al-Qabthiyyah al-Kûfî alDâruquthnî, Sunan al-Dâruquthnî, Bâb al-Shayd wa alDrabâ'ib wa al-Ath'imah wa Ghayru Dralika, hadits 4812. jilid 14 h. 1446 (selanjutnya disebut al-Daruquthni). Dikutip dari Yusrizal Efendi, Praktek Kurban dalam Timbangan Al-Quran dan Sunnah. Makalah disampaikan dalam Muzakarah Ikatan Dai Indonesia (IKADI) Kabupaten Tanah Datar di Masjid Raya Lantai Batu pada hari Sabtu tanggal 15 Dzulqaidah $1430 \mathrm{H} / 23$ Oktober 2009 M

16 Ahmad ibn Hanbal, al-Musnad al-Imam Ahmad ibn Hanbal, Bab Bidayat Musnad 'Abd Allab ibn 'Abbas, (Cairo: Dar al-Hadits, [tth]), jilid VII, h. 23 (selanjutnya disebut Ahmad Ibn Hambal)

17 Abdul Aziz Dahlan, dkk (Ed), Ensiklopedi Hukum Islam 3 IMS-MAJ, (Jakarta: PT. Ichtiar Baru Van Hoeve, 2003), Jilid III, h. 995

18 Ahmad Isya Asyur, op. cit., h. 394. Dalam hal ini ulama sepakat bahwa syarat-syarat bagi orang yang melakukan kurban adalah: muslim, merdeka, baligh, 
Syarat-syarat kurban ini terbagi menjadi dua bagian, yaitu syarat sunnat dan syarat sah kurban. Adapun syarat sunnat adalah syarat bagi orang yang melaksanakan kurban. Sementara itu, syarat sahnya kurban adalah syarat yang harus dipenuhi. ${ }^{19}$

\section{SYARAT SAH KURBAN}

Hewan kurban itu tidak cacat.

Sebagaimana sabda Rasulullah SAW:

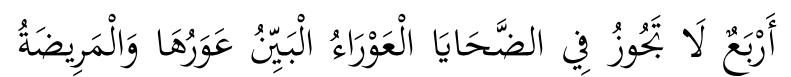

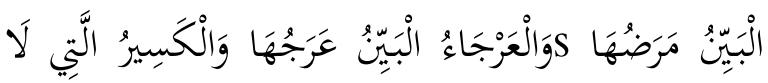

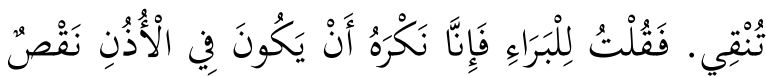

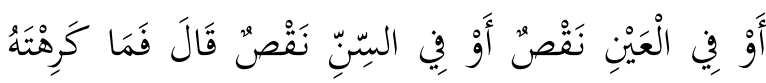

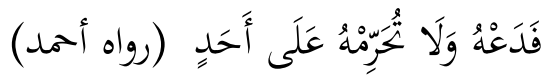

Ada 4 cacat pada hewan yang tidak boleh untuke kurban: 1. juling yang benar-benar juling, 2. sakit yang benar-benar sakitnya, 3. pincang yang benarbenar pincangnya, dan 4. hewan yang sudah tua dan tidak bersumsum lagi. Ubayd ibn Fayruz. mengatakan, Kami juga tidak suka jika telinga bewan itu cacat atau matanya yang cacat atau umurnya yang kurang. Al-Barrâ' menjawab: 'Apa yang tidak kamu sukai, tinggalkanlah, namun jangan dibaramkan atas orang lain (HR. Ahmad). ${ }^{20}$

Kurban itu tidak sah apabila pada badannya terdapat cacat. Hanafiyah berpendapat bahwa kurban itu tidak sah dengan hewan yang buta kedua matanya atau sebelah mata. Tidak juga dengan hewan kurus yang tidak bersumsum, tidak juga dengan hewan pincang yang tidak mampu berjalan ke tempat penyembelihan. Sedangkan hewan pincang yang masih bisa berjalan dengan tiga kaki dan kaki satunya lagi sekedar menapak tanah untuk membantu kaki lainnya berjalan, maka yang demikian itu sah dijadikan kurban. Begitu pula tidak sah berkurban dengan hewan yang terpotong kupingnya atau

\footnotetext{
berakal, penduduk tetap suatu wilayah dan mempunyai kemampuan. Lihat Abdul Aziz Dahlan, Ibid.

${ }^{19}$ Abdurrahman Al-Jaziri, op. cit., h. 352

${ }^{20}$ Ahmad, op. cit., Bab Hadìts al-Barrâ ibn 'Ầîb, hadits 17919 .
}

ekornya atau bokongnya bila sampai lebih dari sepertiga. Sedangkan apabila dua pertiga bokongnya masih ada dan sepertiganya hilang, maka yang demikian sah. Juga tidak sah berkurban dengan hewan ompong, kecuali bila gigi yang ada pada hewan itu lebih banyak dari pada yang tanggal, tidak sah dengan hewan yang dilahirkan tanpa kuping, demikianyang putingnya terpotong yang tidak menghasilkan susu lagi atau yang dilahirkan tanpa bokong atau yang digembala dengan kotoran, sebelum hewan itu dikandangi dan diberi makanan yang bersih. ${ }^{21}$

Adapun ulama fiqh berpendapat mengenai syarat binatang kurban; Pertama, Seluruh ahli fiqih sepakat bahwa hewan kurban harus dari binatang ternak, seperti unta, sapi dan kambing; Kedua, Menurut mazhab Hanafi, Maliki, Syafi'i dan Hanbali, tidak diperbolehkan menyembelih hewan kurban dengan domba (al-dha'n), kecuali jika berupa al-jaaza' (yakni telah berusia enam bulan) dan sapi yang telah berusia lima tahun. Ketiga, Seluruh ahli fiqih sepakat bahwa binatang ternak yang akan dijadikan kurban hendaknya tidak mempunyai cacat, buta sebelah matanya, pincang, sakit, tua tetapi tidak bersumsum (kurus kering) dan bagian dalam tanduknya pecah. Keempat. Dalam menyembelih hewan kurban tidak disyaratkan harus yang jantan, tetapi jika yang hendak disembelih adalah unta atau sapi, maka yang lebih utama adalah betina. Adapun kambing kacang (al-ma'y) dan domba (al-dha'n), yang lebih utama adalah jantan. ${ }^{22}$

Adapun syarat-syarat binatang kurban yang bisa dijadikan sebagai kurban adalah; Jika hewan yang akan menjadi kurban adalah selain dham (domba), maka disyaratkan tsani. Adapun jika hewan yang akan dijadikan sebagai kurban adalah dham, cukup dengan jadra' yaitu berumur enam bulan atau lebih, dan gemuk. Maksud tsani seperti yang disyaratkan untuk

\footnotetext{
${ }^{21}$ Andurrahman Al-Jaziri, op. cit., h. 355

${ }^{22}$ Muhammad Ibrahim Jannati, op. cit., h. 338
} 
selain dham adalah jika hewan berupa, maka unta itu harus berumur lima tahun. Jika hewan berupa sapi, maka sapi itu harus berumur dua tahun dan jika hewan itu berupa kambing maka kambing itu harus berumur satu tahun penuh.

Hewan (yang akan dijadikan kurban) harus dalam kondisi yang sehat. Kalau mengacu pada syarat ini, maka hewan yang matanya buta, kakinya pincang, berpenyakit kulit atau badannya kurus tidak boleh dijadiakan sebagai kurban. Sa'id bin Mansur meriwayatkan dari Hasan, dia berkata, "Para ulama telah menjelaskan bahwa apabila seseorang membeli unta atau hewan kurban dalam keadaan sempurna, kemudian unta atau hewan kurbannya yang sudah dibelinya buta, pincang atau kurus sebelum hari penyembelihan kurban, yaitu tanggal 10 Dzullhijah, dia tetap diperbolehkan untuk menyembelihnya dan hal itu sudah mencukupi. ${ }^{23}$ Sedangkan hewan yang sejak lahir keadaannya memang tidak berekor, maka ia sah dijadikan kurban seperti yang keadaannya memang tidak ada susunya dan tidak berbokong. Beda halnya dengan hewan yang tidak berkuping dari lahir, maka ia tidak sah dijadikan kurban akan tetapi bila kuping itu sekedar sobek atau berlubang bila tidak sampai menghilangkan sebahagian darinya. ${ }^{24}$

Berkurban dengan hewan yang dikebiri hukumnya sah dan pengebirian pada hewan itu boleh dengan tiga syarat; Hendaknya hewan itu dari jenis hewan yang dapat dimakan dagingnya; Pengebirian itu dilakukan pada waktu kecil; Pengebirian itu dilakukan dalam waktu yang singkat. ${ }^{25}$

23 Sayyid Sabiq, op. cit., terjemahan Khairul Amru Harahap dan Masrukhin, judul asli "Fiqh AsSunnah", (Jakarta: Cakrawala Publising, 2008), Cet. 1. h. 152

24 Sayydi Sabiqm, terjemahan khairul Amru Harapah, , h. 361

25 Sayydi Sabiqm, terjemahan khairul Amru Harapah, , h. 361
Jika tidak dilakukan berdasarkan ketiga syarat ini, maka pengebirian itu hukumnya haram. Berkurban juga sah dengan hewan yang pecah tanduknya sekalipun untuk hewan dam, selama tidak menyebabkan pada berkurangnya daging. Sebagaimana juga sah dengan hewan yang keadaannya memang tidak bertanduk sejak lahir, walau yang bertanduk itu lebih utama dan begitu juga sah dengan hewan yang keadaannya ompong sejak lahir. Sedangkan berkurban dengan hewan yang hilang giginya disebabkan suatu hal yang terjadi kemudian, maka yang demikian itu tidak sah, seperti halnya juga tidak sah berkurban dengan hewan yang hilang sebahagian giginya bila sampai berpengaruh pada cara makannya. Jika tidak memberikan pengaruh apa-apa, maka ia sah dijadikan kurban. ${ }^{26}$

Kurban itu sah berupa seekor domba bila umurnya telah genap satu tahun atau telah tanggal gigi depannya dengan syarat tanggalnya gigi depan itu setelah mencapai umur enam bulan. Sah juga berkurban seekor kambing kacang bila umurnya telah genap dua tahun, juga berupa seekor sapi atau kerbau bila umurnya telah genap dua tahun, juga berupa seekor unta bila umurnya telah genap lima tahun. Sedangkan berkurban dengan hewan yang lahir dari percampuran antara hewan piaraan dan hewan liar, maka yang demikian itu tidak sah. ${ }^{27}$

Demikian juga tidak sah berkurban dengan hewan kambing susunya kering, juga yang hilang gigi depannya dari pangkalnya, yang pecah kulit tanduknya dan yang hilang lebih dari separuh bokongnya. Sedangkan apabila yang hilang itu separuh dari bokongnya atau kurang, maka yang demikian sah. Sebagaimana juga tidak sah berkurban dengan hewan yang keadaannya memang tidak bertanduk dari lahir, juga yang sangat kecil
${ }^{26}$ Ibid, h. 361
${ }^{27}$ Ibid. 
kupingnya dan yang keadaan tidak berkuping sejak lahir. ${ }^{28}$

Berkurban dengan hewan yang buntung ekornya dari sejak lahir atau buntung karena terpotong adalah sah. Demikian juga dengan hewan yang dikebiri (dibuang biji pelirnya). Sedangkan berkurban dengan hewan yang dibuang dzakar dan kedua biji pelirnya, yang demikian itu tidak sah. ${ }^{29}$

Berkurban dengan hewan liar hukumnya tidak sah, demikian juga dengan hewan yang dilahirkan dari percampuran (perkawinan) antara yang liar dan hewan piaraan. ${ }^{30}$ Sementara itu, anak domba yang sah dijadikan kurban adalah yang berumur 6 bulan. Hal yang demikian itu diketahui dengan runduknya bulu yang terdapat di atas punggungnya. Sedangkan untuk selain domba, maka sah dijadikan kurban bila telah cukup umur. Kambing kacang yang cukup umur adalah yang sempurna satu tahun, sedangkan untuk umur sapi adalah yang sempurna dua tahun dan untuk umur unta adalah yang sempurna lima tahun memasuki tahun keenam, dibawah umur tersebut tidak sah dijadikan kurban. ${ }^{31}$ Artinya hewan kurban itu harus sempurna, baik dari umurnya maupun bentuk fisiknya. Dan apabila dengan kondisi tertentu, hewan kurban yang tidak sempurna, misalkan ada bagian bagian tertentu dari hewan kurban yang tidak sempurna sebagaimana yang telah di jelaskan di atas) jika tidak ada hewan kurban lain di temukan maka hewan kurban tersebut dapat di gunakan untuk berkurban dan kurbannya sah.

Kurban Dilaksanakan pada waktu yang telah ditentukan.

Mengenai waktu penyembelihan hewan kurban dilaksanakan pada hari Nahar, para ulama berbeda pendapat, menurut Syafi'i,

\footnotetext{
${ }^{28}$ Ibid.

${ }^{29}$ Ibid, h. 363

${ }^{30}$ Ibid

31 Ibid, h. 364
}

waktunya adalah pada hari Nahar (hari penyembelihan) dan hari-hari Tasyrik (tanggal 10-13 Dzulhijah). Sebagaimana riwayat Ahmad ibn Hanbal dari Jubayr ibn Muth'im. Nabi SAW bersabda:

$$
\text { كلُ أَيَّامِ التَّْْرِيقِ ذَبِْح (رواه أحمد) }
$$

Semua hari tasyrik adalah hari penyembelihan hewan kurban (HR. Ahmad). ${ }^{32}$

Jika waktu penyembelihan kurban sudah lewat, sementara hewan kurban yang wajib belum disembelih, maka hewan kurban disembelih sebagai qadha. Menurut Malik dan Ahmad, waktu penyembelihan kurban adalah pada hari-hari penyembelihan, yaitu tanggal 10 hingga 13 Dzulhijah. Dalam salah satu riwayat disebutkan, Abu Salamah bin Abdurrahan dan Nakha'i mengatakan bahwa waktu penyembelihan hewan kurban adalah mulai hari Nahar (hari penyembelihan hewan kurban) hingga akhir Dzulhijah.

Waktu menyembelih kurban adalah tanggal 10 Dzulhijah, menurut ijmak. Ulama telah sepakat bahwa sesudah hari keempat dari Yaumun Nahar itu bukan waktu berkurban, kecuali menurut pendapat Al Hasan bahwa berkurban itu jaiz. sampai masuk bulan Muharram. Menurut ijmak, sebaiknya penyembelihan kurban dikerjakan sesudah shalat Id dan sesudah imam menyembelih. Adapun penyembelihan sebelum terbitnya fajar Yaumun Nahar dan sebelum shalat $T d$, ulama sepakat tidak boleh. Mereka sepakat pula bahwa penyembelihan pada malam hari disyariatkan pula sebagaimana disyariatkan pada waktu siang, kecuali menurut pendapat Malik dan Ahmad. ${ }^{33}$

Waktu penyembelihan binatang kurban adalah dari waktu shalat Idhul Adha sampai matahari terbenam di akhir hari Tasyrik. ${ }^{34}$ hadits 16151

32 Ahmad, op. cit., Bab Hadîts Jubayr ibn Muth'im,

${ }^{33}$ Sa'di Abu Habieb, op. cit., h. 393

${ }^{34}$ Musthafa Diib Al-Bugha, Fikih Islam Lengkap Penjelas Hukum-hukum Islam Mą̧ab Syafï, (Surakarta: Pustaka Arafah, 2009), h. 510 
Sebagaimana firman Allah "Supaya mereka menyaksikan berbagai manfaat bagi mereka dan supaya mereka menyebut nama Allah pada hari yang telah ditentukan atas rezki yang Allah telah berikan kepada mereka berupa binatang ternak". (QS. alHajj: 28)

Hari yang ditentukan ialah hari raya haji dan hari tasyrik, yaitu tanggal 10, 11, 12 dan 13 Dzulhijjah dan dimaksud dengan binatang ternak di sini ialah binatang-binatang yang termasuk jenis unta, lembu, kambing dan biri-biri. Waktu untuk menyembelih kurban bisa di awal waktu yaitu setelah salat $I d$ dan tidak menunggu hingga selesai khutbah. Bila di sebuah tempat tidak terdapat pelaksanaan salat Id, maka waktunya diperkirakan dengan ukuran salat $I d$. Dan barangsiapa yang menyembelih sebelum waktunya maka tidak sah dan wajib menggantinya.

شَاتُُكَ شَاةُ لَّمْ فَقَالَ يَا رَسُولَ اللَّهِ إِنَّ عِنْدِي دَاجِنًا

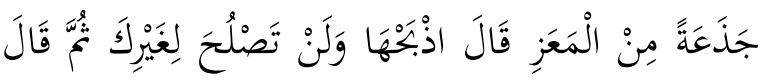

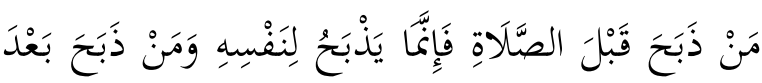

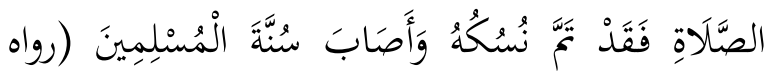

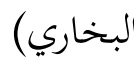

Kambingmu hanyanyalah sembelihan biasa (untuk makan daging), lalu ia berkata: Ya Rasulullah, sesunggubnya saya masib mempunyai kambing jantan jadz'ah (6 bulan). Beliau bersabda: Sembeliblah kambing itu (sebagai kurbanmu) dan sekali tidak boleh bagi orang selain kamu. Siapa yang menyembelih (hewan kurban) sebelum shalat, maka ia banya menyembelih untuk dirinya sendiri dan siapa yang menyembelih seusai shalat, maka sungguh telah sempurna ibadah (kurbannya) dan ia telah sesuai dengan sunnah kaum muslimin (HR. AlBukhari)..$^{35}$

Tidak ada khilafiah di kalangan ulama tentang kebolehan menyembelih kurban di waktu pagi, siang, atau sore, berdasarkan firman Allah Subhanahu wa Ta'ala; 'Dan supaya mereka menyebut nama Allah pada hari yang telah ditentukan”. (Q.S. Al-Haji: 28)

35 hadits 5130. op. cit., h. 7
Mereka hanya berbeda pendapat tentang menyembelih kurban di malam hari. Yang rajii' adalah diperbolehkan, karena tidak ada dalil khusus yang melarangnya. Ini adalah tarjih Ibnu 'Utsaimin rahimahullahu dalam Asy-Syarhul Mumti' dan fatwa Al-Lajnah AdDa imah. Yang dimakruhkan adalah tindakantindakan yang mengurangi sisi keafdhalannya, seperti kurang terkoordinasi pembagian dagingnya, dagingnya kurang segar, atau tidak dibagikan sama sekali. Adapun penyembelihannya tidak mengapa. Adapun ayat di atas (yang hanya menyebut hari-hari dan tidak menyebutkan malam), tidaklah menunjukkan persyaratan, namun hanya menunjukkan keafdhalan saja. Penyembelihan kurban meliputi siang dan malam pada harihari yang di tentukan itu.

Waktu penyembelihan hewan kurban adalah 4 (empat) hari, hari Idul Adha dan tiga hari sesudahnya. Waktu penyembelihannya berakhir dengan tenggelamnya matahari di hari keempat yaitu tanggal 13 Dzulhijjah. Ini adalah pendapat 'Ali bin Abi Thalib radhiyallahu 'anhu, Al-Hasan Al-Bashri Imam penduduk Bashrah, 'Atha' bin Abi Rabah Imam penduduk Makkah, Al-Auza'i Imam penduduk Syam, Asy-Syafi'i Imam fuqaha ahli hadis rahimahumullah. Pendapat ini dipilih oleh Ibnul Mundzir, Ibnul Qayyim dalam Zadul Ma’ad, Ibnu Taimiyah, Al-Lajnah Ad-Da imah dan Ibnu 'Utsaimin dalam Asy-Syarhul Mumti'Alasannya disebutkan oleh Ibnul Qayyim rahimahullahu sebagai berikut: Pertama, Hari-hari tersebut adalah hari-hari Mina. Kedua, Hari-hari tersebut adalah hari-hari tasyriq. Ketiga, Hari-hari tersebut adalah harihari melempar jumrah. Keempat, Hari-hari tersebut adalah hari-hari yang diharamkan puasa padanya. ${ }^{36}$ Rasulullah bersabda: bahwa bebas.com/2011/12/04/waktu penyembelihan hewan kurban/ 
Semua hari tasyriq adalah hari penyembelihan hewan kurban. ${ }^{37}$

Akhir waktu penyembelihan hewan kurban adalah pada akhir hari tasrik. Menurut Imam Asy-Syafi'i, akhir waktu penyembelihan hewan kurban ini sampai tenggelamnya matahari pada hari tasyrik ketiga. Penyembelihan hewan kurban yang terakhir ialah pada tanggal 13 Dzulhijah sebelum matahari terbenam. ${ }^{38}$

Untuk kurban disyariatkan tidak disembelih sesudah terbit matahari pada hari Id, tetapi setelah lewat beberapa saat, seukuran shalat $T d$. Sesudah itu boleh menyembelihnya di hari mana saja yang termasuk hari tiga, baik malam atau siang dan setelah tiga hari tersebut tidak ada waktu penyembelihannya. Sebagaimana yang diriwayatkan oleh Al Bukhari dan Muslim dari rasulullah SAW, beliau Bersabda:

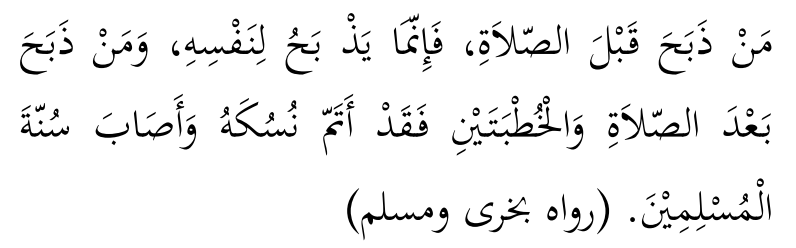

Siapa yang menyembelib sebelum shalat, maka sesunggubnya ia menyembelih untuk dirinya dan siapa yang menyembelih setelah shalat dan dua khutbah, sunggub ibadahnya ia telab sempurnakan dan ia mendapat sunnah kaum muslimin (HR. Bukhari dan Muslim). ${ }^{39}$

Hewan kurban disembelih sesuai dengan pelaksanaan shalat hari raya Idhul Adha, sebagaimana diriwayatkan Al-Bukhari dari Annas ibn Malik, Nabi pernah bersabda pada hari raya kurban (yaum al-nabr):

37 Ahmad, op. cit., Bab Hadits Jubayr ibn Muth'im, hadits 16151, op. cit., h. 8

38 Abu al-Walid Muhammad bin Ahmad bin Muhammad Ibnu Rusyd al-Quthubi al-Andalusi, Bidayatul Mujtabid, terjemahan Imam Ghazali Said dan Ahmad Zaidun, judul asli "Bidayatul Mujtahit wa Nihayatul Muqtashid”, (Jakarta: Pustaka Amani, 2007), Cet. 3 . (Selanjutnya disebut Ibn Rusyd), h. 285

39 Sayyid Sabiq, op. cit., h. 162

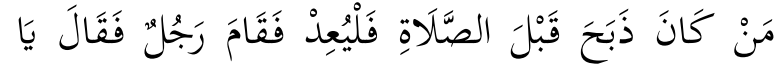

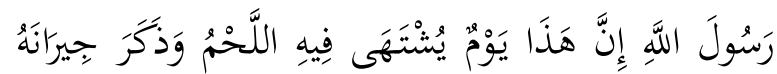

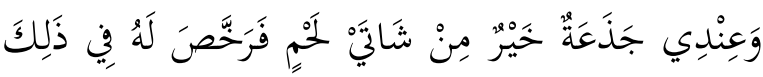

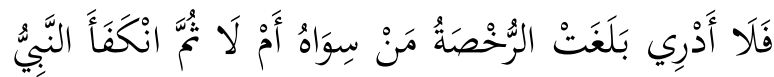

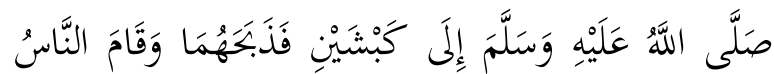

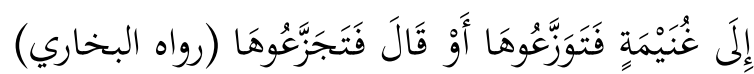
Siapa yang menyembelih (bewan) sebelum shalat, maka hendaklah ia mengulang penyembelihan (kurbannya) kembali. Seorang laki-laki berdiri seraya bertanya: ' $\mathrm{Ya}$ Rasulullah, sesunggubnya pada hari ini disenangi orang (makan) daging, lalu ia teringat tetangganya, dan saya hanya memiliki seekor kambing betina muda (6 bulan) yang (menurutnya) lebih baik (gemuk, berdaging) dari dua ekor kambing (pada umumnya), lalu Nabi pun memberikan dispensasi kepada laki-laki itu dalam keadaan demikian. Kata Anas, saya tidak tabu, apakah dispensasi itu juga berlaku bagi yang lain atankab tidak. Kemudian Nabi SAW berpaling menuju 2 ekor domba, lalu beliau pun menyembelih keduanya, dan orang banyak pun berdiri menuju hewan kurban masing-masing, lalu mereka pun menyembelibnya (HR. Al-Bukhariî). ${ }^{40}$

Dari uraian diatas, menurut penulis waktu penyembelihan hewan kurban adalah setelah sholat hari raya Idhul Adha tanggal 10 Zulhijjah sampa hari Tasrik tanggal 11, 12 dan 13 Zulhijjah.

\section{TATA CARA PENYEMBELIHAN HEWAN KURBAN}

Tata cara penyembelihan adalah dengan menyebut Asma Allah. ${ }^{41}$ Bertakbir dan berdoa waktu menyembelih. Dalam hal ini, Allah berfirman, "Dan telah kami jadikan untuke kamu unta-unta itu sebahagian dari syi'ar Allah, kamu memperoleh kebaikan yang banyak padanya, maka sebutlab olebmu nama Allab ketika kamu menyembelihnya dalam keadaan berdiri (dan telah terikat). Kemudian apabila telah roboh (mati), maka

40 Al-Bukhari, op. cit., Bab Mâ Yasytaby Min alLahm Yaum al-Nabr h. 6 hadits 5123.,

${ }^{41}$ Abdurrahman Al-Jaziri, op. cit., h. 365 
makanlah sebahagiannya dan beri makanlah orang yang rela dengan apa yang ada padanya (yang tidak. meminta-minta) dan orang yang meminta. Demikianlab kami telah menundukkan untua-unta itu kepada kamu, mudab-mudahan kamu bersyukur". (Q.S. Al-Hajj/ 22: 36)

Dalam hadis, Al-Bukhari meriwayatkan dari Anas ibn Malik, ia mengatakan:

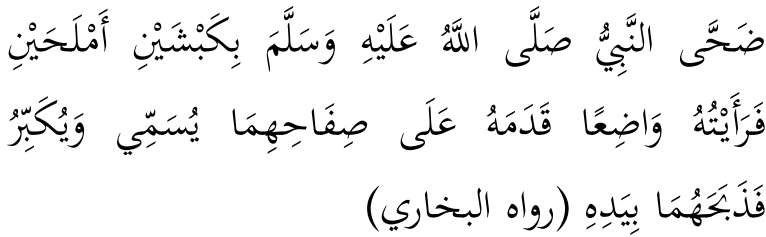

Nabi SAW berkurban dengan 2 ekor kambing yang bagus dan bertanduk, maka aku melibat beliau meletakekan telapak kaki beliau pada kedua sisi hewan itu, seraya membaca basmallahb dan bertakbir, lalu beliau menyembelih kedua hewan kurban itu dengan kedua tangannya (HR. Al-Bukhari). ${ }^{42}$

Sementara itu, Abu Daud meriwayatkan dari Jabir ibn 'Abdillah, ia menceritakan:

قَالَ شَهِهْتُ مَعْ رَسُوِلِ اللَّهِ صَلَّى اللَّهُ عَلَيْهِ وَسَلَّمَ

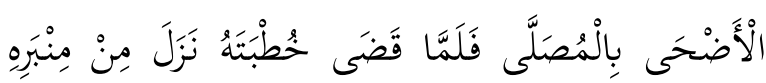

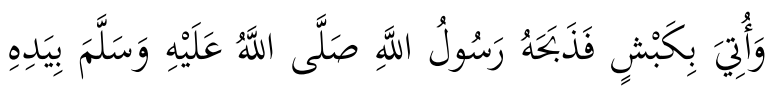

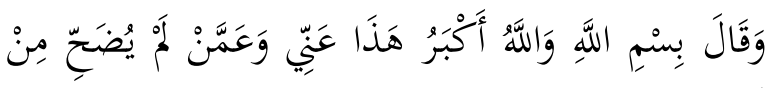
أُمَّتي (رواه أبي داود )

Saya menyaksikan bersama Rasulullab $S A W$ (penyembeliban) kurban di tempat shalat. Sewaktu selesai berkhutbah, beliau pun turun dari mimbarnya, dan dibawakan (untuknya) seekor kambing, lalu Rasulullah SAW menyembelihnya dengan tangannya sendiri, dan beliau membaca bismillâbi wallâhu akbar. Kurban ini dariku dan dari orang yang tidak. berkurban dari umatku. (HR. Abu Dawud). ${ }^{43}$

Dalam riwayat lain yang dikemukakan oleh Muslim dari Aisyah, disebutkan bahwa Rasulullah menyembelih hewan kurbannya

42 Al-Bukhârî, op. cit., Bab Man Dzabaha alAdhâhî bi Yadibi, h. 11 hadits 5132

43 Abu Dawud Sulaiman al- Asyiats al-Hijistani al-Azani, Sunan Abu Dawud, (Mekkah: Maktabat alMakkiyah, [tth] ) jilid Bab Fî al-Syat Yudhaby Biha 'an Jama'ah, hadits 2427, h. 11 seraya membaca basmallah dan doa sebagai termaktub dalam hadis berkut:

أَنَّ رَسُولَ اللَّهِ صَلَّى اللَّهُ عَلَيْهِه وَسَلَّمَ أَمَرَ بِكَبْشِ أَقْرَنَ

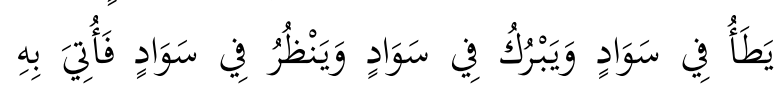

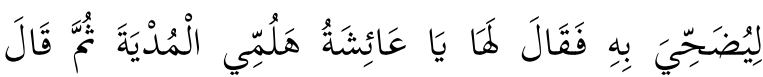

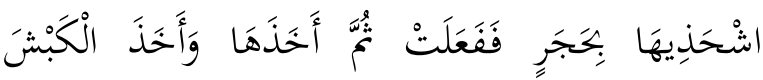

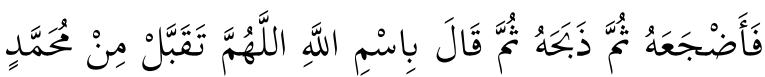

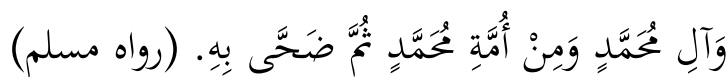
Babwa Rasulullab SAW telah memerintabkan untuk. menyediakan seekor kambing yang bertanduk, yang kaki berwarna hitam, perutnya berwarna hitam, dan bola matanya berwarna bitam, lalu orang membawanya kepada Nabi SAW untuke dikurbankan. Lalu, Nabi SAW bersabda kepada 'Aisyab: Ya 'Aisyah, bawalab pisau. Kemudian beliau berkata lagi: 'Asablah pisau itu dengan batu, lalu ia pun melakukannya, kemudian beliau ambil pisaunya, kemudian beliau ambil kambingnya, lalu beliau baringkan, kemudian beliau menyembelibnya sambil mengucapkan (yang artinya): Dengan nama Allâh. Ya Allâh, terimalah dari Mubammad dan keluarga Mubammad, lalu beliau sembelih kambing tersebut (HR. Muslim). ${ }^{44}$

Secara teknis cara pemotongan hewan yang boleh (halal) dimakan dengan syaratsyarat yang akan dirinci dalam pendapat mazhab. Hanafiyah berpendapat bahwa pemotongan hewan yang sesuai dengan syari'at itu terbagi menjadi dua bagian: pertama, pemotongan darurat (dzakat al-dharurah) dan kedua pemotongan tidak darurat (dzakat alikthiyar). Pemotongan darurat ini dilakukan dengan cara melukai pada bagian mana saja dari badan hewan itu. Ini dilakukan untuk hewan yang tidak jinak. Jika kambing, sapi atau unta menjadi liar dan sulit untuk disembeli, lalu dipanah dan kena pada bagian mana saja dari badannya dan mengeluarkan darah serta mematikan, maka ia halal dimakan. Demikian juga apabila ada unta melarikan diri sedang pemiliknya tidak mampu menangkapnya

${ }^{44}$ Muslim, op. cit., Bab Istibbab al-Dhahayah wa Dzbabuhâ Mubasyarat, h. 12 hadits 3637 
kecuali dengan banyak orang, maka ia boleh memanahnya. Bila unta itu luka dan darahnya mengalir lalu mati karena lukanya itu berarti ia halal dimakan. ${ }^{45}$

Sedangkan pemotongan tidak darurat, dilakukan dengan menyembelih antara ujung kerongkongan dan ujung dada, yaitu dengan cara memotong dua urat leher, yaitu dua urat besar yang terdapat di kedua sisi depan batang leher, dan memotong pembulu nafas serta kerongkongannya. Namun cukup juga dengan memotong tiga di antaranya, sebab lebih banyak hukumnya sama dengan semuanya (lil aktsar bukmul kull). Karena itu, ia harus memotong pembuluh nafas atau kerongkongan beserta dua urat leher; atau memotong satu urat leher, pembulu nafas dan kerongkongan. Sebagian dari mereka memandang perlu memotong pembuluh nafas dan kerongkongan serta salah satu urat leher. Bila pemotongan hewan kurban dilakukan dengan cara tadi, berarti penyembelihan itu sesuai dengan syariat; dan sembelihan tersebut halal dimakan. ${ }^{46}$

Dalam riwayat al-Bayhaqi dari Imran ibn Hushayn, Rasulullah berpesan kepada putrinya Fatimah yang lagi berkurban, sebagai berikut:

يا فاطمة قومي فاشهدي أضحيتك فانه يغفر لك باول قطرة تقطر من دمها كل ذنب عملتيه وقولى (ان صلاتي ونسكى ومحياى ومماتي لله رب العالمين لا شريك له وبذلك امرت وانا اول المسلمين) قلت يارسول الله هذا لك ولاهل بيتك خاصة فاهل ذلك انتم ام للمسلمين عامة قال بل للمسلمين عامة (رواه

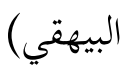

Wahai Fathimah, berdirilah dan saksikanlah (proses penyembeliban) bewan kurbanmu. Sesunggubnya ia menjadi pengampun dosa bagimu seiring tetesan pertama yang menetes dari darahnya untuk setiap

${ }^{45}$ Abdurrahman Al-Jaziri, op. cit., h. 366 dosa yang diperbuat. Bacalah olehmu (yang artinya): 'Sesunggubnya shalatku, ibadabku, kebidupanku, dan kematianku hanyalah untuk Allab Tuban semesta alam. Tidak ada sekutu bagi-Nya dan dengan demikian aku diperintabkan agar menjadi orang yang mula-mula menyerabkan diri'. (Kata Imran ibn Hushayn), aku bertanya, 'Ya Rasulullah, ini banya berlaku untukmu dan keluargamu secara khusus? Ataukah hal itu berlaku bagimu ataukah juga untuk kaum muslimin secara umum?'Beliau menjawab: Namun, juga berlaku bagi kaum muslimin secara umum' (HR. Al-Bayhaqi).

\section{GAMBARAN UMUM LOKASI PENELITIAN}

Penelitian ini bertempat di Nagari Tanjung Barulak Kecamatan Tanjung Emas yang terdiri dari 4 jorong diantaranya Joromg Pintu Rayo, Jorong Balai Baru, Jorong Lingkuang Kawek dan Jorong Padang Datar. Nagari Tanjuang Barulak Kecamatan Tanjung Emas Secara Georgrafis berbatasan dengan Nagari Pagaruyaung sebelah Utara, Kecamatan Padang Gantiang Sebelah Selatan, Nagari Saruaso sebelah Barat dan Kecamatan Lintau Buo sebelah Timur.

Masyarakat Nagari Tanjung barulak berjumlah 5036 48jiwa yang mayoritas pencariannya $70 \%$ sebagai petani, $10 \%$ sebagai peternak, 13\% sebagai Pedagang, 7\% sebagai Pegawai Negeri Sipil

Di Nagari Tanjung Barulak terdapat 2 Masjid, 8 mushola, dan 7 surau yang tiap tahun melaksanakan penyembelihan hewan kurban.49

47 Abu Bakar Ahmad bin al-Husayn bin 'Ali alBayhaqi, Sunan al-Bayhaqi al-Kubra, kitab Al-Adhabi, Bab Ma Yustababbu min Dribhin Shabib, hadits 10.005. Dikutip dari Yusrizal Efendi, Praktek Kurban dalam Timbangan Al-Quran dan Sunnah. Makalah disampaikan dalam Muzakarah Ikatan Dai Indonesia (IKADI) Kabupaten Tanah Datar di Masjid Raya Lantai Batu pada hari Sabtu tanggal 15 Dzulqaidah $1430 \mathrm{H} / 23$ Oktober 2009 M

48 Badan Pusat Statistik Tahun 2017

49 Masjid al-Maaarif dan Masjid Tarhim, mushalla AlMubarak, Mushalla Al-Anshar, Mushalla Muslihin, Mushalla Nurul Iman, Mushalla Nurul Huda, Mushalla 
Pada masing- masing Masjid, Mushalla dan Surau ketika pelaksanaan penyembelihan hewan kurban, maka upah bagi orang yang menyembelih hewan kurban di ambil dari Bagian Hewan Kurban, khususnya kaki, kepala, hati dan dan daging khusus. Ini dilakukan sejak turun temurun yang mana tidak ada yang masyarakat yang mempermasalahan. Pemberian upah pemotongan hewan kurban yang diambil dari bagian i hewan kurban tersebut kepada tukang potong/ penyembeliahan ini merupakan hal yang wajar karena ini merupakan balas jasa yang diberikan patia kurban/ masyarakat atas pemotongan hewan

\section{DINAMIKA UPAH PENYEMBELIHAN HEWAN KURBAN DI NAGARI TANJUNG BARULAK}

Ibadah kurban tiap tahun dilaksanakan oleh kaum muslimin di seluruh Indonesia. Pelaksanaan penyembelihan hewan kubran di tengah-tengah masyarakatpun berbeda-beda antara satu sama lain khususnya pemberian upah penyembelihan hewan kurban. Upah penyembelihan hewan kurban di beberapa tempat diberikan dari bagian hewan kurban diantaranya penulis temukan di salah satu Nagari yang ada di Kabupaten Tanah Datar. Pemberian upah penyembelihan hewan kurban dari bagian hewan kurban ini seperti kepala, daging khusus, kepala dan buntut sudah terjadi sejak dahulunya yaitu turun temurun. Pemberian upah penyembelihan hewan kurban ini dari bagian hewan kurban tersebutpun sudah menjadi kebiasaan dan tidak ada masyarakat yang mempermasalahkan hal itu. Sehingga panitia pun memberikan upah penyembelihan hewan kurban bagian dari hewan kurban tersebut.

Nurul Iman, Nusahlla Nurul Amal, Mushalla AlMunawarh, mushalla Uwa, Surau Kubang, Surau Tanjuang, Surau Limau Asam Surau Bunduang, Surau Jihad dan Surau Muslimin (data dari Tokoh / Ulama Masyarakat, Syahrul, SHI)
Pemberian upah berupa bagian dari hewan kurban (kepala, daging khusus, atau kepala) ini dilakukan dengan alasan bahwa si pemotong dari hewan kurban pun juga berhak mendapatkan bagian dari hewan kurban tersebut. Ini di berikan sebagai bentuk balas jasa atau upah dari pemotongan hewan kurban.

Bagi si penerima daging dari hewan kurban sebagai bentuk upah atau balas jasa yang ia terima ini merupakan bentuk balas jasa terhadap apa yang ia berikan yaitu memotong atau menyembeli hewan kurban.

Upah penyembelihan hewan kurban yang telah dilakukan oleh masyarakat tersebut sudah dilakukan secara turun temurun. Pada masyarakat tersebutpun tidak ada yang mempermasalahkannya serta hal ini dilakukan sebagai balas jasa terhadap pemotongan hewan kurban. Seiring hal itu pun tukang potong hewan kurban pun merasa hal ini wajar ia dapatkan bagian dari hewan kurban dikarenakan ia mengangap ini sebagai balas jasa terhadap apa yang ia lakukan berupa penyembelihan hewan kurban. Hal ini dilakukan oleh masyarakat dikarenakan terhadap pemahaman masyarakat terhadap pemberikan upah penyembelihan hewan kurban berupa daging khusus adalah hal yang wajar. Pada dasarnya didalam islam pun sudah di atur terkait dengan pemberian upah penyembelihan dan pemotongan hewan kurban yaitu dalam hadis. 'Ali ibn Abi Thâlib radhiyallabu 'anbu memberikan informasi kepada 'Abd al-Rahmân ibn Abî Laylâ sebagai berikut:

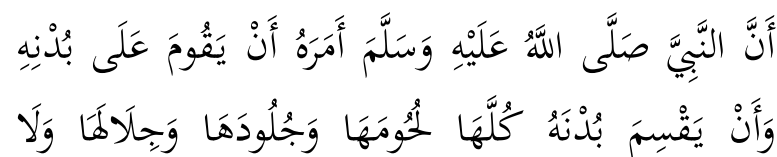

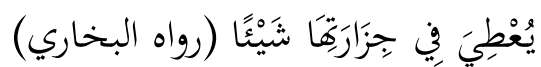

Bahwasanya Nabi pernah menyurubnya untuke mengurus unta (kurban beliau) dan agar membagikan semua unta beliau itu; baik berupa dagingnya, kulitnya, dan pakaiannya, serta tidak diberikan 
kepada orang menyembelibnya sedikit pun (dari bewan kurban itu). (HR. Al-Bukhari) ${ }^{50}$

Senada dengan itu, dalam riwayat lain yang terdapat pada Kitab Shaî̌ Muslim yang juga bersumber dari 'Ali ibn Abî Thâlib, Rasulullah SAW menyuruh untuk menyedekahkan kulit hewan kurban dan tidak justru menjualnya.

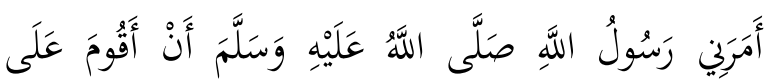

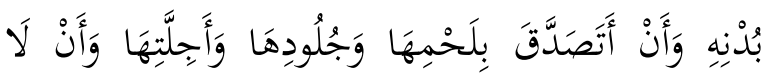

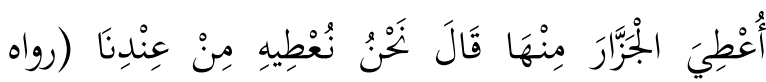

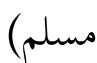

Rasulullab SAW menyurubku untuk mengurus unta (kurbannya) dan untuk menyedekabkan dagingnya, kulitnya, dan pakaiannya, serta untuk tidak memberikan sedikit pun daging kurban kepada (orang) yang menyembelibnya (sebagai upah menyembelih) ". Ali berkata: "Kami suka memberinya (upah) dari kami sendir".' (HR. Muslim). ${ }^{51}$

Hadis di atas menujukkan bahwa tidak boleh memberikan daging kurban kepada orang yang menyembelihnya sebagai upah penyembelihan. Tidak boleh memberikan daging kepada tukang potong sebagai upah karena mereka berhak menerima upah lain sebagai imbalan kerja dan juga tidak halal bagi orang yang berkurban untuk menjual sedikit pun dari hewan kurbannya, baik kulit maupun bulunya.

Demikian pula mengenai pemberian upah pembersihan hewan kurban, upah pembersihan hewan kurban di berikan kepada tukang pembersih hewan kurban di berikan dari bagian hewan kurban seperti bagian kaki,

50. Abu 'Abd Allâh Muhammad ibn Isma'îl ibn Ibrahim ibn al-Mughirat ibn Bardizbat Al-Bukhari alJu'fi, Shabih Al-Bukhari, Kitab l-Adhahi, Bab Idza Ishthalabu 'ala Shulb Jur fa al-Shulb Mardud, (Kairo: alMathaba'ah at-Salafiyah wa Maktabatuha, [t.th.]), Jilid III, h. 21 (Selanjutnya disebut al-Bukhari)

$51 \mathrm{Abu}$ al Husayni Muslim ibn al- Hajjaj alQusyayri al-Nayaburi, Shabih Muslim, Kitab Al-Adhabi, Bab Naqdh Al-Abkam al-Bathilah wa Radd Al-Mubadditsat al-Umur, (Beirut: Dar al-Kutub al-Ilmiyah, 1991 M/1412 H), jilid V, h. 17 (selanjutnya disebut muslim) bagian kepala dan hatinya, dan juga upah tersebut diberikan berdasarkan permintaan tukang pembesih sebagaimana katanya "dek ambo kaki jo lah, dek ambo kapalo jo lah" dan telah terjadi turun temurun.

Larangan memberikan upah pemotongan dari daging hewan kurban adalah berdasarkan hadis. Hal ini disebabkan binatang kurban termasuk (hewan yang disembelih) untuk mendekatkan diri pada Allah). Hasil sembelihannya boleh dimakan, boleh diberikan kepada orang lain, dan boleh disimpan.

Atas dasar itu, tidak tepatlah memberikan upah pemotongan hewan kurban berupa daging kepada tukang potong hewan kurban, sebagaimana yang dipratekkan panitia kurban di Nagari Tanjung Barulak KecamatanTanjung Emas Kabupaten Tanah Datar. ${ }^{52}$ Panitia biasanya memberikan upah pemotongan hewan kurban kepada tukang potong berupa daging yang di khususkan. Panitia kurban berinisiatif memberikan upah pemotongan hewan kurban itu berupa daging yang dikhususkan untuk tukang potong dipandang baik.

Hal ini sesuai dengan metode dalam berijtihad, dimana istishan adalah menganggap sesuatu itu baik. Hal ini sesuai dengan pemberian upah pemotongan hewan kurban tersebut diberikan sebagai balas jasa terhadap orang yang telah memotong hewan kurban.

Panitia kurban beranggapan bahwa pemberian upah pemotongan ini sudah seharusnya diberikan kepada tukang potong. Selain alasan tersebut, masyarakat beranggapan bahwa pemberian upah pemotongan juga merupakan suatu kewajiban atas jasa yang telah diberikan seseorang. ${ }^{53}$

Tindakan pemberian upah pemotongan hewan kurban berupa daging

52 Junaidi ,(Panitia Kurban), Wawancara Pribadi, Jorong Lingkuang Kawek, tanggal 22 Agustus 2018 jam 14.00 WIB

53 Sharul, SHI, (Pengurus Masjid), Wawancara Pribadi, Jorong Lingkuang Kawek, tanggal 23 Agustus 2018 jam 13.00 WIB 
yang di khususkan ditemukan dilakukan di empat Jorong di Nagari Tanjung Barulak KecamatanTanjung Emas Kabupaten Tanah Datar yaitu: Jorong Pintu Rayo, Jorong Padang Datar, Jorong Lingkuang Kawek dan Jorong Balai Baru. Menurut penulis, dilihat dari segi kewajibannya hal ini sudah wajar. Hal ini sesuai dengan hadis yang diriwayatkan Ibnu Majah, Rasulullah SAW bersabda:

$$
\text { عن عبد لله بن عمر قال : قال رسول الله صلى لله }
$$

Dari Abdullah ibnu Umar bahwasanya Rasulullah bersabda: Berikanlah upah kepada pekerja sebelum keringat pekerja itu kering (HR. ibn Majah) ${ }^{54}$

Namun pemberian daging yang di khususkan kepada orang yang memotong hewan kurban itu dianggap tidak tepat, bahwa tukang potong memang harus diberikan upah, tetapi upah tersebut dapat diberikan dari uang iuran dari peserta kurban.

Dari empat Jorong di Nagari Tanjung Barulak, semua Jorong memberikan upah pemotongan hewan kurban itu berupa daging yang di khususkan yang diberikan kepada tukang potong. Menurut penulis, tindakan yang dilakukan di Nagari Tanjung Barulak ini memang bertentangan dengan hadis yang melarang memberikan upah pemotongan hewan kurban berupa daging kepada tukang potong. Jika hendak memberikan upah kepada tukang potong hendaknya peserta kurban memberikan bagian khusus yaitu berupa uang di luar sumbangan untuk hewan kurban.

$$
\text { Adapun alasan masyarakat }
$$

memberikan upah pembersihan dan pemotongan hewan kurban, hal ini telah terjadi turun temurun dan telah menjadi kebiasaan. Kebiasaan dalam masyarakat dapat

54 Abu Abdillah Muhammad ibn Yazid alQazwini ibn Majah. Sunan Ibn Majah, ([t.tp]), Darthya' al-Kutub al-Isratiyyah ([t.th.]), Juz II, h. 817, hadist nomor 2443 diterapkan asalkan kebiasaan tersebut tidak bertentangan dengan norma agama ataupun norma kemasyarakatan.

Demikian pula dari hasil wawancara dengan tokoh msyarakat Nagari Tanjuang Barulak, pemberian upah pembersihan hewan kurban diberikan oleh panitia untuk orang yang membersihkan hewan kurban berupa bagian bagian tertentu seperti kaki, kepala, dan hati dan ada yang diberikan sesuai dengan permintaan tukang pembersihan hewan kurban. jumlahnya sebanyak 1 kantong plastik yang isinya maksimal 2,5 kg. ${ }^{55}$ Panitia kurban memang harus memberikan upah pembersihan kepada tukang pembersihan hewan kurban, namun pemberian upah seperti bagian kepala, kaki, hati tersebut kurang tepat bahwa upah pembersihan hewan kurban itu harus diberikan secara wajar. Panitia kurban bertugas mengatur pemberian upah tersebut secara maksimal.

Hal ini juga dilakukan di empat Jorong yang ada di Nagari Tanjung Barulak yaitu Jorong Pintu Rayo, Jorong Padang Datar, Jorong Lingkuang Kawek dan Jorong Balai Baru. Panitia memberikan upah pembersihan itu diberikan berupa bagian tertentu dari hewan kurban.

Menurut penulis tindakan yang dilakukan di Nagari Tanjung Barulak tentang upah pembersihan hewan kurban ini tidak tepat, karena hal ini sesuai dengan hadis yang melarang memberikan upah pemotongan hewan kurban, penulis beranggapan bahwa upah pemotongan tersebut juga termasuk upah pembersihan hewan kurban dan hal ini dilarang oleh hadis memberikan upah kepada tukang potong hewan kurban.

Dari sini, menurut analisa penulis tidak tepat pemberian upah pemotongan dan pembersihan hewan kurban yang dilakukan di Nagari Tanjung Barulak ketika melakukan ibadah ini dengan memberikan upah

55 J. Paduko Tuan,(Pemuka Masyarakat), Wawancara Pribadi, Tanjung Barulak tanggal 25 Agustus 201* Jam 14.30 WIB 
pemotongan dan pembersihan hewan kurban dengan daging hewan kurban. bahwa untuk memberikan upah pemotongan berupa daging hewan kurban terdapat hadis khusus yang melarangnya. Islam melarang memberikan upah pemotongan dan pembersihan hewan kurban berupa daging sebagaimana 'Ali ibn Abi Thâlib radbiyallabu 'anbu memberikan informasi kepada 'Abd al-Rahman ibn Abi Layla. Jadi pemberian upah pemotongan dan pembersihan hewan kurban yang dilakukan oleh masyarakat tersebut haram hukumnya jika upah pembersihan dan pemotongan di ambil dari daging hewan kurban tersebut. Menurut analisa penulis upah pemotongan hewan kurban harus diambil dari uang iuran peserta kurban saja.

\section{KESIMPULAN}

Pelasaksanaan peyembelihan hewan kurban ditengah tengah masyarakat dilaksanakan berbeda-beda. Ada yang sudah sesuai dengan ketentuannya ada pula yang dilaksanakan sesuai dengan kebiasaan. salah satu kebiasaaan masyarakat yang masih dilakukan pada saat penyebelihan hewan kurban adalah pemberian upah penyembelihan hewan kurban yang diambil dari bagian hewan kurban. Hal ini disebabkan karena hal ini merupakan tradisi yang sudah turun temurun, kedua upah yang diberikan dalam bentuk daging, kepala, kaki atau bagian dari hewan kurban merupakan sebagai balas jasa terhadap orang yang memotong atau membersihkan hewan kurban. Upah tersebut tetap diberikan tetapi tidak mengambil dari bagian hewan kurban kemudian mengganti upah tersebut berupa uang yang diambil atau diminta serta dipungut dari para peserta kurban. 


\section{DAFTAR KEPUSTAKAAN}

Abdul Aziz Dahlan, Ensiklopedi Hukum Islam, 2003, Jakarta: PT Ichtiar Baru van hoeve, , Cet. 1, Jilid. 6

Abdurrahman Al- Jaziri, Figh Empat Mazhab, 2002, terjemahan Chatibul Umam dan Abu Hurairah, judul asli “Al-Fiqh 'Ala Al-Madzabih Al-Arba’ah, Jakarta: Darul Ulum Pres, Jilid. 4

Abû 'Abd Allâh Muhammad ibn Ismâ'îl ibn Ibrâhîm ibn al-Mughirat ibn Bardizbat Al-Bukhârî alJu'fî, Shahîh Al-Bukhârî, Dikutip dari al-Maktabah al-Syâmilah al-Ishdâr al-Tsânî Versi 2.11 .

Abû al-Husayn Muslim ibn al-Hajjaj al-Qusyayri al-Naysaburi, Shabih Muslim Dikutip dari alMaktabah al-Syâmilah al-Ishdâr al-Tsânî Versi 2.11

Amir Syarifuddin, 2001, Ushul Fiqh (jilid dua), Jakarta PT. Logos Wacana Ilmu,

Dendy Sugono, dkk, 1994, Kamus Besar Bahasa Indonesia,Jakarta: Balai Pustaka,

Imam Muhaddist Abi Abdullah Muhammad Bin Zaid al-Qoswaini, Sunan Ibnu Majah Dikutip dari al-Maktabah al-Syâmilah al-Ishdâr al-Tsânî Versi 2.11

Jaih Mubarak, 2003, Fiqh Kontemporer (Dalam Bidang Peternakan),Bandung, CV. Putaka Setia,

Muhammad 'Uwaidah, Kamil, 2008, Fiqih Wanita, terjemahan M. Abdul Ghaffar e.m, judul asli “ Al-Jami’ Fii Fighi An-Nisa”,(Jakarta: Pustaka Al-Kautsar, Cet, II,

Muhammad Ibrahim Jannati, Figh Perbandingan Lima Mą̧hab, 2007, terjemahan Ibnu Alwi Bafaqih, dkk, judul asli, "Durus fi al-Fiqh al-Muqaran", Jakarta: Cahaya, , Cet. 1,

Muhammad Jawad Mughiyah, 2011, fiqih lima marhab, terjemahan musykur A.B. dkk, judul asli "Al-Fiqh 'ala al-madzabih al-khamsah", Jakarta: Lentera, , Cet. 27,

Nana Syaodih Sukmadinata, Metode Penelitian Pendidikan, (Bandung: PT. Remaja Rosdakarya, 2009),

Sa'di Abu Habieb, Ensiklopedi Ijmak, 2006, terjemahan M. Sahal Machfudz dan A. Mustofa Bisri, (Jakarta: PT. Pustaka Firdaus, Cet. IV

Sayyid Quthb, 1984, al-'Adalah al-Ijtima'iyyah fil Islam (tarjamab).Bandung, Pustaka,

Sayyid Sabiq, 2006, Fiqih Sunnah, Jakarta Pena pundi aksara

www.Almanhaj.or.id 